\title{
Effects of rumen-protected methionine or methionine analogs in starter on plasma metabolites, growth, and efficiency of Holstein calves from 14 to $91 \mathrm{~d}$ of age
}

\author{
Rodrigo A. Molano, ${ }^{1} \odot$ Akira Saito, ${ }^{2}$ Daniel N. Luchini, ${ }^{3} \odot$ and Michael E. Van Amburgh ${ }^{1 *} \odot$ \\ ${ }^{1}$ Department of Animal Science, Cornell University, Ithaca, NY 14853 \\ ${ }^{2}$ The National Federation of Dairy Co-operative Associations (Zen-Raku-Ren), Tokyo, Japan 151-00053 \\ ${ }^{3}$ Adisseo USA Inc., Alpharetta, GA 30022
}

\begin{abstract}
During weaning, methionine (Met) supply decreases as liquid feed intake is reduced and ruminal function is developing. During this transition, the calf starter should both promote ruminal development and provide adequate nutrients post-ruminally. In mature ruminants, rumen-protected Met (RPM) and the Met analogs, 2-hydroxy-4-(methylthio)-butanoic acid (HM$\mathrm{TBa}$ ) and HMTBa isopropyl ester (HMBi), are used to increase Met supply, stimulate ruminal fermentation, or exert both effects, respectively. To evaluate the effects of these forms of Met on calf performance during development of ruminal function, 74 Holstein calves were raised until $91 \mathrm{~d}$ of age, in 2 enrollment periods. Calves were individually housed from birth and, at $14 \mathrm{~d}$ of age, balanced for sex and randomly assigned to receive a starter with no added Met (CTRL, $\mathrm{n}=20$ ) or one supplemented with RPM (Smartamine M, Adisseo USA Inc., Alpharetta, GA; n = 16), HMTBa (RumenSmart, Adisseo; $\mathrm{n}=19$ ), or HMBi (MetaSmart, Adisseo; $\mathrm{n}=$ 19). Milk replacer [28\% crude protein $(\mathrm{CP}), 15 \%$ fat] was offered up to $1.6 \mathrm{~kg}$ of dry matter $(\mathrm{DM}) / \mathrm{d}$ and fed 3 times daily. Weaning was facilitated from d 49 to 63 . The 4 starters $(25 \% \mathrm{CP}, 2.5 \mathrm{Mcal}$ of metabolizable energy $/ \mathrm{kg}$ of DM) were offered ad libitum, and supplement inclusion was set to provide an additional $0.16 \%$ DM of Met equivalents, and equal amounts of HMTBa within the analogs. Body weight and stature were measured, and blood was collected and analyzed for plasma urea nitrogen, $\beta$-hydroxybutyrate, and free AA on a weekly basis. Supplementation of RPM and HMBi increased free plasma Met, but no differences in growth or feed efficiency compared with calves fed the CTRL starter could be attributed to the additional Met supply alone. The addition of HMBi in the starter increased feed intake and body weight during the last weeks of
\end{abstract}

Received April 1, 2020.

Accepted July 7, 2020.

*Corresponding author: mev1@cornell.edu the experiment. On the contrary, HMTBa failed to increase plasma Met and depressed intake and growth after weaning, likely because the level included in the diet was too high and intake was greater than previous studies, exacerbating the level of HMTBa ingested. No differences were observed in stature, feed efficiency, or non-AA plasma measurements among groups. These results demonstrate that RPM and HMBi are effective sources of metabolizable Met; however, Met was apparently not limiting calves fed the basal diet in this study. The increased feed intake observed with the inclusion of $\mathrm{HMBi}$ in the starter during the weaning and early postweaning period might be mediated by its metabolism in the rumen, and further research is needed to determine the mechanisms involved.

Key words: dairy calf, performance, weaning, rumenprotected Met, analog

\section{INTRODUCTION}

An optimal dairy replacement program should be constructed to provide adequate management and nutrition to dairy heifers during the entire course of development. However, weaning represents a challenge for maintaining nutrient balance and meeting the targeted growth rates until the calf adapts to the ruminant state (Weary et al., 2008). A nutritional strategy to facilitate this process should be based on a diet with ingredients and nutrient profiles that would both enable an improved ruminal fermentation for rapid ruminal development at low levels of intake and supply the calf with an adequate profile of high intestinally digestible nutrients to maintain the target growth rate during development of ruminal function.

During weaning and early after weaning, calves require as much MP and AA for lean tissue growth as they do before weaning (Van Amburgh et al., 2019). However, the quantity and quality of protein available to the calf changes markedly as the liquid feed offered is reduced, whereas intake and digestion of solid feed is still insufficient (Leibholz, 1975; Quigley 
et al., 1985). Therefore, body protein synthesis could be limited during this phase by a suboptimal supply of AA. Under practical conditions, solid feeds contain notably less protein than whole milk or milk replacers, and if adequate fermentable and digestible substrates are available without concomitant protein supplies, weaning efficiency might be compromised. According to the National Research Council guidelines (NRC, 2001), solid diets containing no more than $19 \%$ of CP could sustain gains of up to $0.9 \mathrm{~kg} / \mathrm{d}$ for weaned calves weighing 50 to $100 \mathrm{~kg}$. When the $\mathrm{CP}$ content of the solid feed is increased, benefits in calf performance have been inconsistent (Luchini et al., 1991; Hill et al., 2007; Stamey et al., 2012). Part of the lack of consistency in these results might be due to differences in rumen degradation and AA digestibility of the undegraded fraction of the protein fed, or the fermentable carbohydrate profile of the starter that might not allow calves to achieve sufficient intake and rapid rumen development (Suárez et al., 2006).

Methionine has been identified as the first limiting AA in dairy calves (Schwab et al., 1982; Abe et al., 1998). However, balancing starters for AA could be difficult to achieve using only conventional ingredients, without overfeeding protein and increasing feed cost. Therefore, methionine-rich sources represent a useful alternative, and rumen-protected forms of Met are suitable for increasing post-ruminal supply in ruminants (Zanton et al., 2014). Alternatively, analogs of Met, such as DL-2-hydroxy-4(methylthio)-butanoic acid (HMTBa) or its isopropyl ester form (HMBi) can be used. Although HMTBa is an effective source of Met for nonruminant animals, it is much less so for mature ruminants, because 50 to $99 \%$ is metabolized in the rumen, with its main effect on ruminal fermentation (St-Pierre and Sylvester, 2005; Martin et al., 2013). In the case of HMBi, it has been determined that approximately half is absorbed and converted into Met and the rest is metabolized in the rumen of adult cattle (Graulet et al., 2005). Thus, HMBi could offer a double benefit to transitioning calves, as it has the potential to both stimulate ruminal fermentation and increase Met supply. However, in the developing rumen of a calf, the effectiveness of these 2 Met analogs is uncertain.

This study was designed to evaluate the effect of supplementing 1 rumen-protected and 2 different ana$\log$ forms of Met during the transition and postweaning periods on the performance and blood metabolites of dairy calves with target growth rates of $1.0 \mathrm{~kg} / \mathrm{d}$ or greater. Our hypothesis was that Met is a limiting AA for calves during the transition phase and Met analogs might facilitate ruminal development, as determined through responses in DMI and growth.

\section{MATERIALS AND METHODS}

\section{Animals and Housing}

All protocols involving animals were reviewed and approved by the Cornell University Institutional Animal Care and Use Committee (Ithaca, NY). Seventyfour Holstein calves (37 female and 37 male) born at the Cornell University Ruminant Center (Harford, NY) were enrolled as they were born. Mature BW of the herd was $759 \pm 46 \mathrm{~kg}$ (mean $\pm \mathrm{SD}$ ). Within the first $2 \mathrm{~h}$ of life, calves received $4 \mathrm{~L}$ of fresh colostrum via esophageal feeder. Twelve hours after birth, an additional $2 \mathrm{~L}$ of colostrum were fed via nipple bottle, and all colostrum used for feeding was at least 21 on the Brix scale. When no colostrum higher than $21 \%$ on the Brix scale was available, colostrum replacer (Colostrum150; Oxford Ag, Greeley, CO) was fed after being reconstituted with water $\left(46^{\circ} \mathrm{C}\right)$. Before their first colostrum, calves received 2 oral scour vaccines (Ecolizer + C20, Novartis, Basel, Switzerland; and Calf-Guard, Zoetis, Parsippany, NJ), a 2-mL subcutaneous vaccine against clostridial infection (Bar Vac CD, Boehringer Ingelheim, Duluth, GA), and a 3-mL subcutaneous injection of selenium and vitamin E supplement (Bo-Se, Merck Animal Health, Kenilworth, NJ). At d 2, blood was collected, plasma separated, and total proteins measured using a digital refractometer (Palm Abbe DD3, Misco, Solon, OH) to evaluate passive transfer of immunoglobulins from colostrum. At this time, calves also received $2 \mathrm{~mL}$ of an intranasal vaccine (Inforce 3, Zoetis) as a preventative for respiratory illness.

After the second colostrum feeding, calves were moved to a naturally ventilated, ambient-temperature calf barn and housed individually in pens $2.4 \mathrm{~m}$ long $\times 1.2 \mathrm{~m}$ wide $\times 1.2 \mathrm{~m}$ high, until 13 wk of age. Pens were placed over a gravel base and bedded with straw; clean finely chopped straw was added daily, and bedding was removed and changed biweekly. Pens allowed visual contact between calves. Any treatments for illness were performed by Cornell University Ruminant Center personnel, following established standard operating procedures. During the experimental period, June 2018 to January 2019, average daily temperature in the calf barn was $11.3^{\circ} \mathrm{C}$, ranging from -20.7 to $34.6^{\circ} \mathrm{C}$. Relative humidity was $80.6 \%$ on average and ranged from 26.6 to $100 \%$.

\section{Feeds and Feeding Management}

Calves were offered milk replacer (Excelerate, Milk Specialties Global, Eden Prairie, MN; Table 1) starting at a feeding rate of $0.85 \mathrm{~kg}$ of $\mathrm{DM} / \mathrm{d}$ and increasing over 
the first $21 \mathrm{~d}$ up to a maximum of $1.7 \mathrm{~kg}$ of DM/d. Milk replacer was reconstituted at $15 \%$ solids and offered at $39^{\circ} \mathrm{C} 3 \times$ a day $(0600,1400$, and $2200 \mathrm{~h})$ with 4 -L nursing bottles. For the first $21 \mathrm{~d}$, a yeast culture with enzymatically hydrolyzed yeast supplement $(0.25 \mathrm{~g} / \mathrm{L}$; Celmanax SCP, Church and Dwight Inc., Princeton, NJ) was diluted in the milk replacer. At $49 \mathrm{~d}$ of age, the weaning process was started by removing $0.45 \mathrm{~kg}$ of DM and then approximately $0.1 \mathrm{~kg}$ of $\mathrm{DM} / \mathrm{d}$ until d 63 , when milk replacer was completely eliminated from the diet.

At $14 \mathrm{~d}$ of age, calves were randomly assigned to receive a control starter (CTRL, $\mathrm{n}=20$ ) or one supple- mented with rumen-protected Met (RPM, $\mathrm{n}=16)$, HMTBa $(\mathrm{n}=19)$, or HMBi $(\mathrm{n}=19)$. Randomization into treatments was blocked to obtain balanced groups for calf sex ( $50 \%$ females, $50 \%$ males), calves coming from primiparous (20\%) and multiparous cows (80\%), dam parity $(3.0 \pm 0.18)$, and dam calving ease $(1.1 \pm$ 0.04 , on a scale of 1 to 5 , where 1 is no difficulty, unassisted, and 5 is extreme difficulty).

Textured calf starters were specifically formulated for this study and offered ad libitum (Table 1). The CTRL starter grain, the base for all treatments, was formulated to obtain a nutrient profile and density to meet the needs for ruminal development and ME and

Table 1. Ingredients of the formulated textured starters, and chemical composition of milk replacer and starters fed

\begin{tabular}{|c|c|c|c|c|c|}
\hline \multirow[b]{2}{*}{ Item } & \multirow[b]{2}{*}{$\mathrm{MR}^{1}$} & \multicolumn{4}{|c|}{ Calf starter ${ }^{2}$} \\
\hline & & CTRL & $\mathrm{RPM}$ & НMTBa & $\mathrm{HMBi}$ \\
\hline DM, $\%$ & 94.20 & 88.70 & 88.70 & 88.30 & 88.60 \\
\hline \multicolumn{6}{|l|}{$\begin{array}{l}\text { Ingredient composition, \% of DM } \\
\text { Pellet }\end{array}$} \\
\hline \multicolumn{6}{|l|}{ Pellet } \\
\hline $\begin{array}{l}\text { Wheat middlings } \\
\text { Treated vegetable meal }\end{array}$ & - & $\begin{array}{l}22.18 \\
13.57\end{array}$ & $\begin{array}{l}22.04 \\
13.49\end{array}$ & $\begin{array}{l}22.18 \\
13.57\end{array}$ & $\begin{array}{l}22.17 \\
13.57\end{array}$ \\
\hline Soybean meal & - & 6.88 & 6.84 & 6.88 & 6.88 \\
\hline Dried whey & - & 6.19 & 6.15 & 6.19 & 6.19 \\
\hline Blood meal & - & 5.86 & 5.82 & 5.86 & 5.86 \\
\hline Dextrose & - & 3.44 & 3.42 & 3.44 & 3.44 \\
\hline HMTBa product ${ }^{4}$ & - & - & - & 0.37 & - \\
\hline HMBi product ${ }^{5}$ & - & - & - & - & 0.73 \\
\hline Vegetable oil & - & 0.70 & 0.70 & 0.70 & 0.70 \\
\hline Minerals & - & 1.20 & 1.20 & 1.20 & 1.20 \\
\hline Vitamin ADE premix & - & 0.30 & 0.30 & 0.30 & 0.30 \\
\hline Yeast components $^{6}$ & - & 0.70 & 0.70 & 0.70 & 0.70 \\
\hline Flavor/odor enhancer & - & 0.30 & 0.30 & 0.30 & 0.30 \\
\hline Lasalocid $^{7}$ & - & 0.30 & 0.30 & 0.30 & 0.30 \\
\hline Flaked corn & - & 20.96 & 20.84 & 20.96 & 20.96 \\
\hline Beet pulp shreds & - & 13.77 & 13.68 & 13.77 & 13.77 \\
\hline Molasses & - & 3.69 & 3.67 & 3.32 & 2.96 \\
\hline Rumen-protected Met $^{8}$ & - & - & 0.30 & - & - \\
\hline \multicolumn{6}{|l|}{ Chemical composition, ${ }^{9} \%$ of DM } \\
\hline Crude protein & 28.50 & 24.80 & 24.50 & 25.00 & 25.20 \\
\hline aNDFom $^{10}$ & - & 21.20 & 21.50 & 20.90 & 20.60 \\
\hline Starch & - & 20.60 & 20.00 & 18.60 & 18.80 \\
\hline Ethanol-soluble sugars & - & 14.80 & 14.60 & 14.70 & 15.00 \\
\hline Soluble fiber & - & 7.70 & 8.40 & 9.30 & 9.10 \\
\hline Crude fat & 15.00 & 3.30 & 3.40 & 3.20 & 4.10 \\
\hline Ash & 6.82 & 7.70 & 7.50 & 7.70 & 7.90 \\
\hline $\mathrm{ME},{ }^{11} \mathrm{Mcal} / \mathrm{kg}$ & 4.60 & 2.50 & 2.50 & 2.50 & 2.50 \\
\hline \multicolumn{6}{|c|}{${ }^{1} \mathrm{MR}=$ milk replacer, Excelerate (Milk Specialties Global, Eden Prairie, MN). } \\
\hline \multicolumn{6}{|c|}{$\begin{array}{l}{ }^{2} \text { Textured calf starters with no added Met (CTRL), rumen-protected Met (RPM), 2-hydroxy-4-(methylthio } \\
\text { butanoic acid (HMTBa), or isopropyl ester of HMTBa (HMBi). }\end{array}$} \\
\hline \multicolumn{6}{|c|}{${ }^{3}$ AminoMax (Afgritech, Watertown, NY). } \\
\hline \multicolumn{6}{|c|}{${ }^{4}$ RumenSmart (88\% HMTBa; Adisseo USA Inc., Alpharetta, GA). } \\
\hline \multicolumn{6}{|c|}{${ }^{5}$ MetaSmart (57\% HMBi; Adisseo USA Inc.). } \\
\hline \multicolumn{6}{|c|}{${ }^{6}$ Celmanax SCP (Church and Dwight Inc., Princeton, NJ). } \\
\hline \multicolumn{6}{|c|}{${ }^{7}$ Bovatec 91 (Zoetis, Parsippany, NJ). } \\
\hline \multicolumn{6}{|c|}{${ }^{8}$ Smartamine M (75\% Met; Adisseo USA Inc.). } \\
\hline \multicolumn{6}{|c|}{${ }^{9}$ As reported by the manufacturer for milk replacer, and as measured for the starters. } \\
\hline${ }^{10}$ aNDFom $=$ amylase and sodium $\mathrm{s}$ & , ash-fr & & & & \\
\hline
\end{tabular}


MP allowable gain for a 110-kg calf, growing at 1.1 $\mathrm{kg} / \mathrm{d}$ and consuming $3 \mathrm{~kg} \mathrm{DM} / \mathrm{d}$, using the Cornell Net Carbohydrate and Protein System (CNCPS) version 6.55 (Van Amburgh et al., 2015a). The amounts of additional Met to be supplemented were based on estimated AA requirements and supply from the CNCPS, both v. 6.55 (Van Amburgh et al., 2015a,b) and v. 7 (Higgs and Van Amburgh, 2016), accounting for feed AA, microbial AA, and endogenous AA supplies at the small intestine, along with intestinal digestibility. In addition, a body composition data set from several published experiments (Diaz et al., 2001; Tikofsky et al., 2001; Bartlett et al., 2006; Stamey et al., 2012) was used to aid in estimating the AA requirements for the preweaned and weaning calves, in combination with the predictions from the CNCPS. A daily requirement of $6.5 \mathrm{~g}$ of Met and $6.0 \mathrm{~g}$ of Cys, corresponding to $3.1 \%$ of the total MP requirement, were estimated. And because Cys is not considered in the current nutritional models, the NEAA requirements were estimated using tissue AA composition data (Williams, 1978), and the estimated metabolizable Met supply was taken into account to meet the estimated metabolizable sulfur AA requirements.

Inclusion of RPM (Smartamine M, Adisseo USA Inc., Alpharetta, GA) and HMBi (MetaSmart, Adisseo; 57\% $\mathrm{HMBi}$ ) were set to provide an additional $0.16 \%$ DM of metabolizable Met, whereas the Met hydroxy analog source (RumenSmart, Adisseo; 88\% HMTBa) was set to equal the amount of HMTBa provided by the HMBi supplement (HMBi is $78 \% \mathrm{HMTBa}$ ). The control and Met analog-containing starters were manufactured at a commercial feed mill (Poulin Grain, Newport, VT). The RPM starter was mixed in a small commercial cement mixer, adding the RPM source and molasses, in equal proportion, to the CTRL starter as a base. Fresh water was available ad libitum.

\section{Measurements and Sample Collection}

Body weight and hip and wither heights were measured weekly between 4 and $6 \mathrm{~h}$ after the morning feeding. Milk replacer intake was recorded at every feeding, and starter intake was recorded at the morning feeding. Starter refusals were measured and then frozen until analysis for DM. Samples of starters and milk replacer were taken monthly, frozen, and composited for DM analysis, chemical composition, and AA content. Blood was collected weekly from wk 2 to $13,4.20 \pm 0.02 \mathrm{~h}$ after the morning feeding, and was taken by jugular venipuncture using a Vacutainer system and collection tubes with sodium heparin (Beckton Dickinson, Franklin Lakes, NJ).

\section{Feed and Supplement Analysis}

Monthly starter samples and daily refusals were analyzed for DM by drying in a forced-air oven at $65^{\circ} \mathrm{C}$ for 48 h. Subsamples of the RPM starter were kept as offered and sent for stability and inclusion rate analysis of the rumen-protected source (Adisseo Centre d'Analyze, de Recherche et d'Appui Technique, Commentry, France). Composited starter samples, as offered and refused, were ground through a 2-mm screen using a Wiley mill. Starter samples were analyzed for amylase-treated and sodium sulfite-treated ash-free NDF (Van Soest et al., 1991; Mertens, 2002), starch (Hall, 2009), and sugars (DuBois et al., 1956). Additionally, DM (method 930.15), ash (method 942.05), and CP (method 990.03) were analyzed according AOAC (2000) methods, and crude fat was determined following method 2003.05 (AOAC, 2006). These analyses were performed at a commercial laboratory (Cumberland Valley Analytical Services, Waynesboro, PA). For AA content determination, milk replacer powder and 1-mm ground starter samples were analyzed by HPLC following hydrolysis at $110^{\circ} \mathrm{C}$ in a block heater for 16,72 , and $168 \mathrm{~h}$ for Trp, and for 21, 72, and $168 \mathrm{~h}$ for other AA, following the procedure described by Fessenden et al. (2017). The highest concentration obtained from the hydrolysis time course was reported, because this was considered to best represent the AA content in the feed (Rutherfurd, 2009).

\section{Analysis of Blood Parameters}

Immediately after collection, blood was placed on ice and analyzed for hematocrit within $2 \mathrm{~h}$ of collection. Hematocrit, as percentage of the total blood volume, was measured by centrifuging microcapillary tubes with heparinized blood for $13 \mathrm{~min}$ at room temperature. Samples were then centrifuged at $3,000 \times g$ and $4^{\circ} \mathrm{C}$ for $20 \mathrm{~min}$. Plasma was separated, aliquoted in $1.7-\mathrm{mL}$ microcentrifuge tubes, and stored at $-20^{\circ} \mathrm{C}$ until analysis. An additional aliquot was prepared for free AA analysis, mixing equal volumes $(0.7 \mathrm{~mL})$ of plasma and a protein precipitation reagent (Seraprep, Pickering Laboratories, Mountain View, CA), with glucosamic acid added as internal standard, vortexed extensively, and refrigerated on ice for $12 \mathrm{~h}$ with occasional vortexing. Then, samples were centrifuged $(15,800 \times g$ for $10 \mathrm{~min}$ at $4^{\circ} \mathrm{C}$ ) and $0.6 \mathrm{~mL}$ of supernatant were filtered through a $0.2-\mu \mathrm{m}$ filter and frozen at $-20^{\circ} \mathrm{C}$ until analysis. Plasma urea nitrogen (PUN) and BHB concentration were measured as described by Chaney and Marbach (1962) and Williamson et al. (1962) on the heparinized plasma, using enzymatic colorimetric 
assays based on commercial kits (respectively No. 640, Sigma-Aldrich, St. Louis, MO; and $\beta$-Hydroxybutyrate Liquicolor, Stambio Laboratory, Boerne, TX). Plasma urea nitrogen and BHB were measured for wk 2, 7 , 9, and 13. Amino acids and 3-methylhistidine were separated for samples taken on wk 9 and 13, via an automated ion-exchange chromatography system, using an Agilent 1100 series HPLC (Agilent Technologies, Santa Clara, CA) fitted with a lithium cation exchange column using a 4-buffer step gradient and column temperature gradient. Detection of separated AA was performed using a Pinnacle PCX post-column ninhydrin derivation (Pickering Laboratories), at 440 and $570 \mathrm{~nm}$, for Pro and the remaining AA.

\section{Calculations and Statistical Analysis}

The number of animals to be enrolled was based on power calculations that indicated that 15 to 20 individuals per treatment were needed to detect differences in ADG or DMI $(0.3-0.4 \mathrm{~kg} / \mathrm{d})$ with a minimum statistical power of $80 \%$ and significance of 0.05 in an $\mathrm{F}$ distribution.

Milk replacer protein digestibility was considered to be $93 \%$ (NRC, 2001). Metabolizable protein and Met supply from the starter were predicted using the CNCPS v. 6.55. This resulted in $148 \mathrm{~g}$ of MP $(71 \%$ from RUP and $29 \%$ from bacteria) and $2.83 \mathrm{~g}$ of MP Met (60\% from RUP and $40 \%$ from bacteria) being supplied for each kilogram of DM consumed of control starter. Default Met metabolizability for Smartamine M was $80 \%$, whereas for the HMTBa in RumenSmart and MetaSmart, 6 and 50\% were used, respectively (Graulet et al., 2005; Noftsger et al., 2005). Dry matter and nutrient intakes were summarized by week, and feed efficiency was calculated by dividing BW gain over the DMI during the period analyzed. Considering average hematocrit at $\mathrm{d} 2(29.86 \pm 0.53 \%)$ and the subsequent weekly samples $(35.3 \pm 0.12 \%)$, plasma measurements were adjusted to 30 and $35 \%$ hematocrit, respectively, to account for any variation in hydration status among the calves (Quigley and Drewry, 1998).

Enrollment periods were from June to July and from October to November 2018. The measurements from birth to the end of wk 2 were analyzed as a randomized block design using a mixed-effects model that included the fixed effect of treatment and the random effect of enrollment period as block and body measurements at birth were used as a covariate for analysis of performance measures taken between birth and the initiation of treatments. At the beginning of the treatment period, the BW at the end of wk 2 was used as a covariate for DMI and growth analysis, and hip and wither heights were used as a covariate for body growth for the rest of the experiment. Data collected throughout the treatment period (wk 3 to 13) were analyzed as a repeated-measures design employing a mixed-effects model that included the random effect of calf and the fixed effects of treatment, week, and week $\times$ treatment interaction. Week was defined as a categorical variable. The body measurements (BW and heights) and the individual calf ADG up to the beginning of the treatment period were used as covariates for the analysis of growth responses and for the analysis of feed intake, feed efficiency, and nutrient supply.

To satisfy the model assumptions of normal and homogeneous distribution of the residuals, natural logarithm transformation was performed for plasma BHB concentration analysis. All analyses were performed using R (v. 3.6.0; R Core Team, 2019) with the "Ime4" package (Bates et al., 2015) "Imer ()" function. A random intercept model was used, and $P$-values were derived using the Satterthwaite approximation method. Least squares means were compared using Fisher's protected least significant difference, using the "emmeans" package (Lenth et al., 2019) in R. Least squares means and standard errors are reported. Significance was declared at $P \leq 0.05$, and trends were stated at $0.05<$ $P \leq 0.10$.

\section{RESULTS}

Total plasma proteins at $\mathrm{d} 2$ of life averaged $7.34 \pm$ $0.28 \mathrm{~g} / \mathrm{dL}$ and did not vary between calves assigned to the different treatments $(P=0.29)$, indicating that passive transfer of immunity was achieved in the calves on this study.

\section{Feed Nutrient Composition}

Starter ingredients and feed nutrient composition are summarized in Table 1. The chemical composition of the starters as offered and refused were not different (data not shown); therefore, only the composition as offered is reported. The AA composition of feeds is shown in Table 2 and demonstrates that the RPM starter had a greater Met concentration than the other starters, as intended. Analysis of the RPM starter mix reported $0.31 \pm 0.05 \%$ inclusion of Smartamine, which had $99 \pm$ $3.67 \%$ protection integrity.

\section{Feed, Metabolizable Energy, and Metabolizable Protein Intake}

Calves consumed similar quantities of milk replacer before being allocated to the treatments $(0.86 \pm 0.01$ $\mathrm{kg}$ of DM/d, $P>0.61)$. The data in Table 3 summarize feed DM, ME, and MP intake during the study. Milk 
Table 2. Amino acid content (\% DM) of the milk replacer and formulated starters

\begin{tabular}{|c|c|c|c|c|c|}
\hline \multirow[b]{2}{*}{ Item, $\%$ of DM } & \multirow[b]{2}{*}{$\mathrm{MR}^{1}$} & \multicolumn{4}{|c|}{ Calf starter ${ }^{2}$} \\
\hline & & CTRL & $\mathrm{RPM}$ & HMTBa & $\mathrm{HMBi}$ \\
\hline \multirow{2}{*}{\multicolumn{6}{|c|}{ EAA }} \\
\hline & & & & & \\
\hline Arg & 0.67 & 1.19 & 1.01 & 1.04 & 1.16 \\
\hline His & 0.50 & 0.71 & 0.72 & 0.71 & 0.72 \\
\hline Ile & 1.55 & 0.78 & 0.76 & 0.77 & 0.74 \\
\hline Leu & 2.63 & 1.82 & 1.89 & 1.84 & 1.90 \\
\hline Lys & 2.15 & 1.29 & 1.28 & 1.31 & 1.29 \\
\hline Met & 0.73 & 0.49 & 0.85 & 0.47 & 0.47 \\
\hline Phe & 0.90 & 0.98 & 1.01 & 1.02 & 1.05 \\
\hline Thr & 1.70 & 0.86 & 0.82 & 0.81 & 0.92 \\
\hline Trp & 0.76 & 0.56 & 0.46 & 0.45 & 0.52 \\
\hline Val & 1.55 & 1.34 & 1.31 & 1.29 & 1.32 \\
\hline \multicolumn{6}{|l|}{ NEAA } \\
\hline Ala & 1.26 & 1.15 & 1.17 & 1.16 & 1.20 \\
\hline Asp & 2.57 & 1.98 & 1.99 & 1.98 & 2.08 \\
\hline Cys & 0.70 & 0.45 & 0.41 & 0.42 & 0.44 \\
\hline Glu & 4.27 & 3.21 & 3.25 & 3.24 & 3.37 \\
\hline Gly & 0.56 & 0.99 & 1.03 & 1.01 & 1.00 \\
\hline Pro & 1.75 & 1.42 & 1.53 & 1.52 & 1.49 \\
\hline Ser & 1.35 & 1.02 & 0.98 & 0.95 & 1.12 \\
\hline Tyr & 0.90 & 0.74 & 0.71 & 0.70 & 0.79 \\
\hline Total AA & 26.09 & 20.99 & 21.17 & 20.69 & 21.59 \\
\hline
\end{tabular}

${ }^{1} \mathrm{MR}=$ milk replacer, Excelerate (Milk Specialties Global, Eden Prairie, MN).

${ }^{2}$ Textured calf starters with no added Met (CTRL), rumen-protected Met (RPM), 2-hydroxy-4-(methylthio)butanoic acid (HMTBa), or isopropyl ester of HMTBa (HMBi).

replacer intake (on absolute or BW basis) did not differ among treatments. Differences in starter consumption were observed only after weaning, at which point the Met analogs supplementation exerted contrary effects on starter intake (Figure 1). From wk 10 until the end of the experiment, intake of the HMTBa starter was lower than that of the CTRL $(P<0.06)$ and HMBi diets $(P<0.04)$. Compared with RPM, the inclusion of HMTBa also affected intake during wk $12(P=$ $0.07)$ and $13(P=0.05)$. During the last 2 weeks of the experiment, calves on the HMBi diet consumed more starter than did those on the CTRL and RPM starters $(P<0.02)$. However, when analyzed as a percentage of BW, starter intake did not differ among groups. Intake of RPM and CTRL starters was similar during the experiment $(P>0.47)$.

Overall, total DMI and ME supply were affected by treatment, being lower for calves fed the HMTBa starter relative to those receiving the $\mathrm{HMBi}$ starter $(P<0.02)$. Not surprisingly, over time, differences in total DMI and ME supply resembled those observed in starter intake. Thus, calves fed the HMTBa starter had lower ME supply after weaning compared with those consuming the HMBi $(P<0.05)$ and CTRL starters $(P<0.09)$, while also showing a tendency toward lower ME supply than calves fed the RPM starter during the last 2 wk of the experimentation $(P<0.10$, Figure 2$)$.
Calves consuming the starter with HMBi had a greater MP supply than those offered the CTRL $(P=$ $0.02)$ or the HMTBa starters $(P<0.01)$, particularly during the last $2 \mathrm{wk}$ of the experiment $(P<0.01)$. At wk 13, the HMBi group also had a greater MP supply than did the RPM-fed calves $(P<0.01)$. By the end of the experiment, HMTBa tended to get less MP than did those on the CTRL $(P=0.08)$ or RPM starters $(P$ $=0.10)$.

At wk 8, a tendency for higher DMI $(P=0.08)$ and greater ME and MP supplies $(P=0.01)$, compared with CTRL, were detected for calves consuming the RPM starter. This group also had a tendency for higher ME $(P=0.08)$ and a greater MP supply $(P=0.05)$ relative to the HMTBa calves.

\section{Methionine Intake}

The absolute Met intake, calculated by taking into account the measured Met concentration and intakes and refusals of the different starters, and the estimated metabolizable Met supplies, are shown in Table 3. During the study, RPM calves consumed the most Met $(P$ $<0.01$ ), and those fed the HMTBa consumed the least Met $(P<0.06)$. Following the progression of starter intake, differences started to be detected just before weaning (wk 7), when Met intake of the RPM-fed group 
was significantly higher than that of the HMTBa calves $(P=0.02)$ and tended to be greater that that of the CTRL group. Thereafter, the starter containing RPM allowed greater Met intakes than the other starters did $(P<0.01)$. In agreement with the differences detected in starter intake and the slightly lower Met content of the HMTBa starter, calves assigned to HMTBa consumed less Met than those on the HMBi $(P<0.06)$ and CTRL starters $(P<0.02)$ from wk 10 to the end of treatment.

The model predictions indicated that the metabolizable Met supplied, both as per day or as per $\mathrm{kg}$ of metabolic weight $\left(\mathbf{M B W}, \mathrm{BW}^{0.75}\right)$, was highest by the starter with RPM $(P<0.01)$, followed by that from the HMBi group $(P<0.01)$, which was not different from the HMTBa and CTRL groups $(P=0.76$, Table $3)$. These differences started to be evident at wk 5 and were consistent with the onset of weaning (Figure 2).

\section{Growth and Feed Efficiency}

At birth, the calves did not differ among treatments in BW (42.39 $\pm 06 \mathrm{~kg}, P=0.71)$, wither height (76.61 $\pm 0.46 \mathrm{~cm}, P=0.48)$ or ,hip height $(80.91 \pm 0.50 \mathrm{~cm}$, $P=0.35)$. At the initiation of treatment, BW (50.69 \pm $0.53 \mathrm{~kg}, P=0.95)$, wither height $(78.95 \pm 0.44 \mathrm{~cm}, P$
$=0.34)$, hip height $(85.10 \pm 0.59 \mathrm{~cm}, P=0.81)$, and their respective rates of gain $(0.67 \pm 0.03 \mathrm{~kg} / \mathrm{d}, 0.18 \pm$ $0.03 \mathrm{~cm} / \mathrm{d}$, and $0.35 \pm 0.03 \mathrm{~cm} / \mathrm{d}, P>0.63)$ were not different among treatments. During the experiment, calves on the Met-supplemented starters grew at a similar rate than those in the CTRL group, but calves consuming the HMBi starter tended to grow faster (vs. RPM, $P=0.07)$ or grew significantly faster than the animals on the other supplements (vs. HMTBa, $P<$ 0.01 , Table 3).

Through the preweaning period, calves grew at 0.97 $\pm 0.02 \mathrm{~kg} / \mathrm{d}, 0.75 \pm 0.03 \mathrm{~kg} / \mathrm{d}$ during weaning, and then at $1.31 \pm 0.02 \mathrm{~kg} / \mathrm{d}$ thereafter. Average BW was not affected by treatment (Table 3) but started to differ among groups after the first week postweaning (Figure 3). By the end of the experiment, calves assigned to the HMBi starter were heavier than their counterparts $(136.62 \mathrm{~kg}, P<0.03)$, whereas those consuming the starter including RPM $(131.33 \mathrm{~kg})$ had similar weights to the calves on the CTRL $(133.09 \mathrm{~kg}$, $P=0.29)$ and HMTBa diets $(128.86 \mathrm{~kg}, P=0.14)$. On the other hand, individuals fed the HMTBa starter were lighter than those in the CTRL $(P<0.01)$ and HMBi groups $(P<0.01)$. Overall, birth weight doubled before weaning was initiated and tripled by the end of the experiment. Stature measurements and rates of

Table 3. Least squares means of feed DM and nutrient intakes, BW, ADG, and feed efficiency for calves consuming a starter with no added Met (CTRL) or one containing rumen-protected Met (RPM), 2-hydroxy-4-(methylthio)-butanoic acid (HMTBa), or isopropyl ester of HMTBa (HMBi) from 14 to $91 \mathrm{~d}$ of age

\begin{tabular}{|c|c|c|c|c|c|c|c|}
\hline \multirow[b]{2}{*}{ Item } & \multicolumn{4}{|c|}{ Treatment group $^{1}$} & \multirow[b]{2}{*}{$\mathrm{SEM}^{2}$} & \multicolumn{2}{|c|}{$P$-value ${ }^{3}$} \\
\hline & CTRL & $\mathrm{RPM}$ & HMTBa & $\mathrm{HMBi}$ & & TRT & $\mathrm{TRT} \times \mathrm{Wk}$ \\
\hline MR intake, \%BW & 1.57 & 1.59 & 1.58 & 1.59 & 0.02 & 0.91 & 0.90 \\
\hline Starter intake, $\mathrm{kg} / \mathrm{d}$ & 1.38 & 1.39 & 1.30 & 1.44 & 0.05 & 0.16 & $<0.01$ \\
\hline Starter intake, \%BW & 1.31 & 1.33 & 1.24 & 1.35 & 0.04 & 0.20 & 0.36 \\
\hline Total DMI, kg/d & $2.14^{\mathrm{ab}}$ & $2.16^{\mathrm{ab}}$ & $2.06^{\mathrm{b}}$ & $2.21^{\mathrm{a}}$ & 0.05 & 0.10 & $<0.01$ \\
\hline MP supply, ${ }^{5} \mathrm{~g} / \mathrm{d}$ & $417.98^{\mathrm{b}}$ & $425.36^{\mathrm{ab}}$ & $410.64^{\mathrm{b}}$ & $439.50^{\mathrm{a}}$ & 6.87 & 0.01 & $<0.01$ \\
\hline Met intake, $g / d$ & $12.46^{\mathrm{bc}, \mathrm{x}}$ & $17.42^{\mathrm{a}}$ & $11.84^{\mathrm{c}, \mathrm{y}}$ & $12.61^{\mathrm{b}}$ & 0.25 & $<0.01$ & $<0.01$ \\
\hline MP Met supply, ${ }^{5} \mathrm{~g} / \mathrm{d}$ & $9.30^{\mathrm{c}}$ & $13.40^{\mathrm{a}}$ & $9.23^{\mathrm{c}}$ & $11.77^{\mathrm{b}}$ & 0.18 & $<0.01$ & $<0.01$ \\
\hline MP Met supply, $\mathrm{g} / \mathrm{kg}^{0.75}$ & $0.32^{\mathrm{c}}$ & $0.44^{\mathrm{a}}$ & $0.32^{\mathrm{c}}$ & $0.39^{\mathrm{b}}$ & 0.00 & $<0.01$ & $<0.01$ \\
\hline BW wk $7, \mathrm{~kg}$ & 92.34 & 91.97 & 91.47 & 93.41 & 0.92 & 0.42 & $<0.01$ \\
\hline $\mathrm{ADG}, \mathrm{kg} / \mathrm{d}$ & $1.07^{\mathrm{ab}}$ & $1.05^{\mathrm{ab}, \mathrm{y}}$ & $1.01^{\mathrm{b}}$ & $1.11^{\mathrm{a}, \mathrm{x}}$ & 0.03 & 0.04 & 0.49 \\
\hline Feed efficiency ${ }^{6}$ & 0.54 & 0.52 & 0.53 & 0.54 & 0.01 & 0.70 & 0.42 \\
\hline
\end{tabular}

${ }^{\mathrm{a}-\mathrm{c}}$ Means in the same row with different superscripts differ $(P \leq 0.05)$.

${ }^{\mathrm{x}, \mathrm{y}}$ Means in the same row with different superscripts differ $(0.05<P \leq 0.1)$.

${ }^{1} \mathrm{CTRL}, \mathrm{n}=20 ; \mathrm{RPM}, \mathrm{n}=16 ; \mathrm{HMTBa}, \mathrm{n}=19 ; \mathrm{HMBi}, \mathrm{n}=19$.

${ }^{2}$ Largest SEM is shown.

${ }^{3}$ Significance of the fixed effects of treatment $(\mathrm{TRT})$, and week $\times$ treatment interaction. Week effect $(P<0.01)$ present for all parameter estimates.

${ }^{4} \mathrm{MR}=$ milk replacer.

${ }^{5}$ Estimated ME, MP, and metabolizable Met supply calculated using the Cornell Net Carbohydrate and Protein System v. 6.55 model (Van Amburgh et al., 2015a). Metabolizable Met supply from supplements was $80 \%$ of Met in RPM, $6 \%$ of HMTBa, and $50 \%$ of $\mathrm{HMBi}$.

${ }^{6} \mathrm{ADG} / \mathrm{DMI}$. 
gain (data not shown) did not differ among groups $(P$ $>0.59)$. Overall rates of linear growth were $0.21 \pm 0.01$ $\mathrm{cm} / \mathrm{d}(P=0.87)$ for withers and $0.23 \pm 0.01 \mathrm{~cm} / \mathrm{d}(P$ $=0.92$ ) for hip height.

Feed efficiency decreased as calves progressed in the study and was not affected by the treatments (Table 3 ). Feed efficiencies were $0.65 \pm 0.01,0.44 \pm 0.02$, and 0.42 \pm 0.01 before, during, and after weaning, respectively.

\section{Plasma Free Amino Acid Concentration}

Circulating concentrations of free AA were analyzed at wk 9 and 13, corresponding to the period when calves were consuming starter only. The plasma molar concentration of free Met, AA related to Met metabolism, 3 -methylhistidine, and the combined concentration of all essential, nonessential, and total AA are reported in Table 4. Plasma concentration of Met and AA related to its metabolism are also reported as a percentage of total assayed AA. Molar concentrations of most AA were affected by week, being generally highest at wk 13. No differences were identified in circulating 3-methylhstidine or combined levels of essential, nonessential, or total AA. At wk 9, differences in free Met were

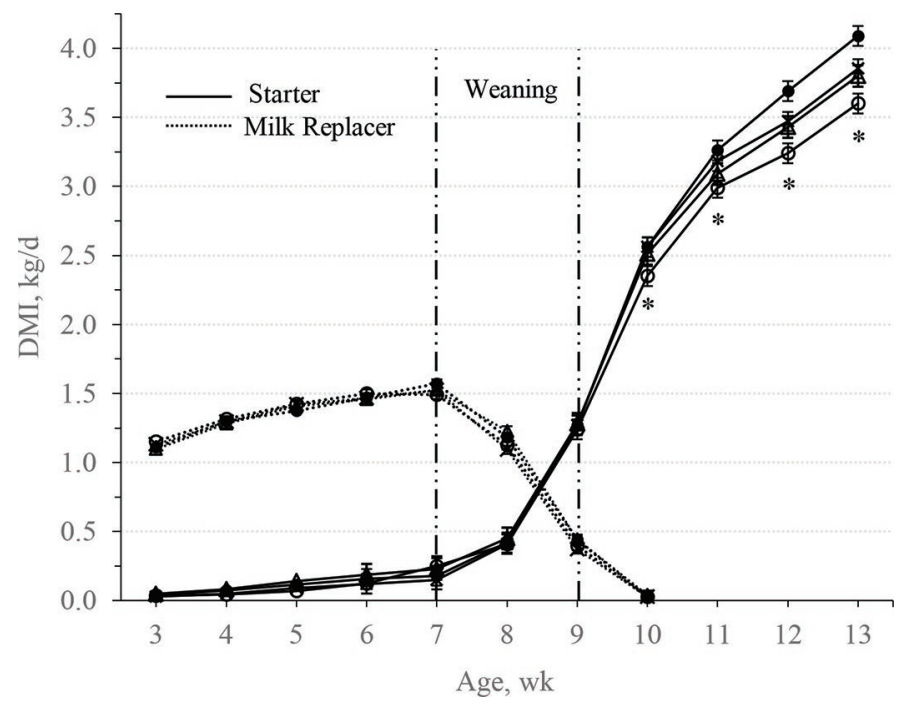

Figure 1. Least squares means for DMI of milk replacer and calf starter of calves receiving a starter with no added Met (CTRL, $\times)$ or one containing rumen-protected Met (RPM, $\Delta$ ), 2-hydroxy4-(methylthio)-butanoic acid (HMTBa, O) or isopropyl ester of HMTBa $(\mathrm{HMBi}, \bullet)$. Vertical bars represent SE. Effect of week $(P<$ 0.01). Effect of week $\times$ treatment interaction for milk replacer $(P=$ $0.33)$ and starter intake $(P<0.01)$ : weeks labeled with $*$ denote differences in starter intake between treatments as follows. Wk 10: HMTBa vs. CTRL or HMBi $(P<0.05)$; wk 11: HMTBa vs. CTRL $(P=0.06)$ or HMBi $(P<0.01)$; wk 12: HMBi vs. all other treatments $(P<0.03)$, HMTBa vs. CTRL $(P=0.02)$ or RPM $(P=0.07)$; wk 13 : HMBi vs. other treatments $(P<0.02)$ and HMTBa vs. other treatments $(P<$ $0.05)$. Weaning was initiated at wk 7 , and all liquid feed was removed by wk 9 . detected, with both RPM and HMBi groups having higher concentrations than CTRL $(P<0.05)$, whereas the treatment calves fed HMTBa had lower Met concentrations than calves fed RPM $(P=0.03)$ but similar to those in the other 2 groups $(P>0.17)$. When analyzed as proportion of total AA, Met concentrations showed similar results, except that they tended to differ between the groups supplemented with the analogs $(P$ $=0.06$ ). Similarly, a tendency for lower proportion of circulating Ser in the RPM fed group compared with CTRL $(P=0.10)$ was identified. No other differences were detected among groups at the end of weaning.

At the end of the experiment, animals consuming the starter with added RPM had the highest plasma Met concentrations of all groups $(P<0.02)$, whereas calves consuming the HMBi starter had higher plasma Met concentration than those in the CTRL and HMTBa $(P<0.01)$ groups. Similar differences were detected when the plasma Met concentrations were analyzed relative to the total AA content in plasma. Differences in circulating Gly were also detected between groups.

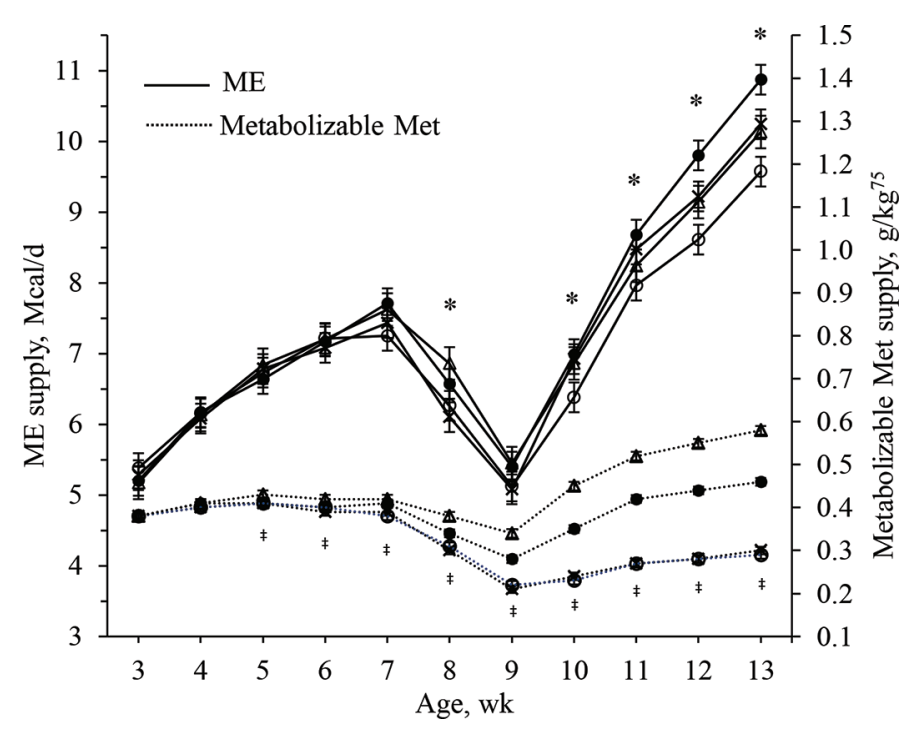

Figure 2. Least squares means for estimated ME and Met supply for calves receiving a starter with no added Met $(\mathrm{CTRL}, \times)$ or one containing rumen-protected Met (RPM, $\Delta$ ), 2-hydroxy-4-(methylthio)butanoic acid (HMTBa, O), or isopropyl ester of HMTBa (HMBi, $)$. Vertical bars represent SE. Effect of week $(P<0.01)$ and week $\times$ treatment interaction $(P<0.03)$ : weeks labeled with $*$ denote differences in metabolizable energy supply between treatments as follows. Wk 8: RPM vs. CTRL $(P=0.01)$; wk 10 and 11 : HMTBa vs. CTRL $(P<0.10)$ or HMBi $(P<0.05)$; wk 12 and 13 : HMBi vs. all other treatments $(P<0.05)$, HMTBa vs. CTRL $(P<0.05)$ or RPM $(P<$ $0.10)$. Weeks labeled with $\ddagger$ denote differences in metabolizable Met supply among treatments as follows. Wk 5 : RPM vs. other treatments $(P<0.10)$; wk 6 : RPM vs. CTRL $(P=0.08)$; wk 7 : RPM vs. CTRL $(P=0.04)$ or $\operatorname{HMTBa}(P<0.01)$, and HMBi vs. HMTBa $(P=0.02)$; wk 8 to 13: RPM vs. other treatments $(P<0.01)$ and HMBi vs. other treatments $(P<0.02)$. Weaning was initiated at wk 7 , and all liquid feed was removed by wk 9 . 


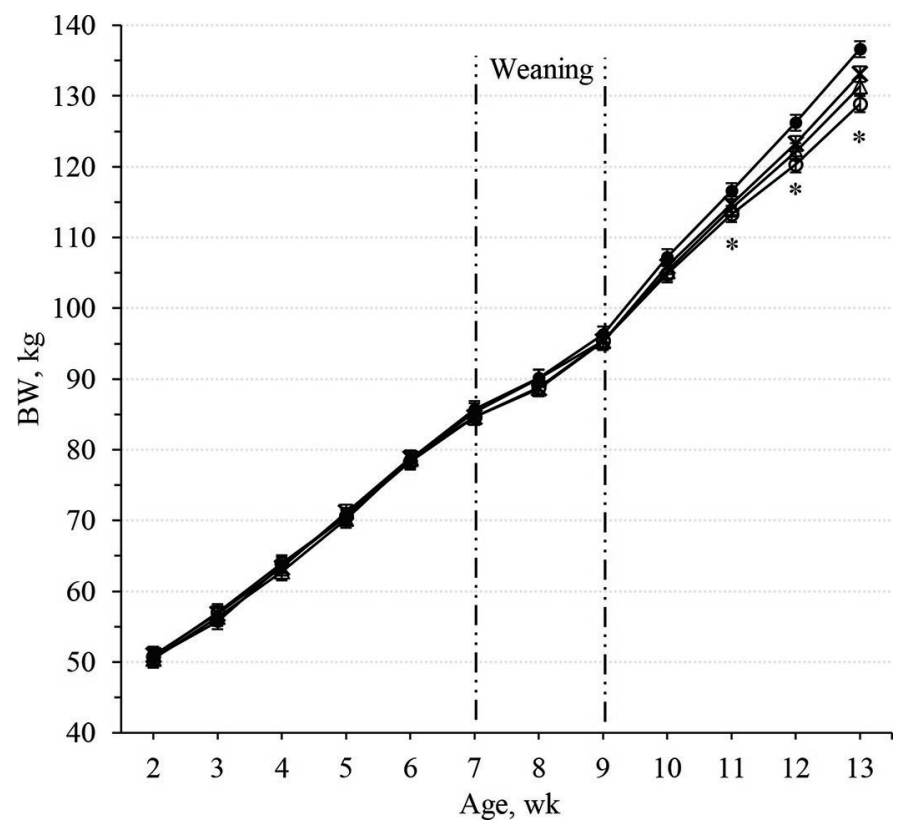

Figure 3. Least squares means for BW of calves consuming a starter with no added Met $(\mathrm{CTRL}, \times)$ or one containing rumen-protected Met (RPM, $\Delta$ ), 2-hydroxy-4-(methylthio)-butanoic acid (HMTBa, O), or isopropyl ester of HMTBa $(\mathrm{HMBi}, \bullet)$. Vertical bars represent SEM. Effect of week and week $\times$ treatment interaction $(P<0.01)$ : weeks labeled with $*$ denote differences between treatments as follows. Wk 11: HMBi vs. $\operatorname{HMTBa}(P=0.05)$; wk 12: HMBi vs. CTRL $(P=0.06)$, $\operatorname{RPM}(P=0.02)$, or HMTBa $(P<0.01)$. HMTBa vs. CTRL $(P=$ $0.07)$; wk 13: HMBi vs. all other treatments $(P<0.03)$, and HMTBa vs. CTRL $(P<0.01)$. Weaning was initiated at wk 7 , and all liquid feed was removed by wk 9 .

When analyzed as a proportion of total AA, plasma Gly was highest in the HMTBa-supplemented calves $(P$ $<0.01)$ and lowest in the RPM-supplemented group $(P$ $<0.07)$. Likewise, although treatments did not affect Ser molar concentrations in plasma, when analyzed as proportion of total circulating AA, it was evident that Ser levels in calves offered the HMTBa starter were significantly higher than those of their counterparts $(P$ $<0.01$ ). For the other individual AA assayed (data not shown), differences were also identified in the circulating levels of His, Phe, and Orn, which were decreased by the inclusion of HMTBa in the starter, compared with the other groups $(P<0.08)$.

\section{Plasma BHB and PUN}

Given the association between ruminal fermentation and butyrate production, and the transformation of this volatile fatty acid into BHB, plasma BHB has been proposed as an indirect indicator of ruminal activity in dairy calves (Deelen et al., 2016). In this study, plasma BHB concentrations increased with age $(P<0.01)$ but were not affected by treatment $(P=0.40)$. As expected, circulating concentrations of BHB were low just before weaning $(0.09 \pm 0.003 \mathrm{mmol} / \mathrm{L})$ and rapidly increased once weaning started, reaching $0.29 \pm 0.01$ and $0.50 \pm$ $0.02 \mathrm{mmol} / \mathrm{L}$ at 9 and $13 \mathrm{wk}$, respectively.

The PUN levels were used to indirectly evaluate the effects of the different sources of Met supplementation on $\mathrm{N}$ utilization. Plasma urea nitrogen levels were unaffected by treatment $(P=0.60)$ but increased with age $(P<0.01)$ starting at $11.93 \pm 0.33 \mathrm{mg} / \mathrm{dL}$ before weaning, increasing to $14.40 \pm 0.33 \mathrm{mg} / \mathrm{dL}$ by wk 9 , and reaching $15.08 \pm 0.33 \mathrm{mg} / \mathrm{dL}$ by wk 13 of the experiment.

\section{DISCUSSION}

The objective of the study was to evaluate 3 sources of Met supplementation, and this was achieved using an RPM source and 2 analogs, under conditions that allowed calves to grow close to their biological potential during the experiment, averaging $1 \mathrm{~kg}$ ADG. This is an important distinction, as previous studies that aimed to evaluate different levels of $\mathrm{CP}$ in starter (Luchini et al., 1991; Hill et al., 2007; Stamey et al., 2012) or AA supplementation after weaning (Williams and Smith, 1974; Abe et al., 1998), never surpassed $0.8 \mathrm{~kg} / \mathrm{d}$ ADG, and energy allowable gain and ME intake can influence the interpretation of AA requirements.

Prior to weaning, ADG and feed efficiencies observed in this study were similar to those of other studies where calves followed an enhanced feeding program based on a nearly ad libitum allowance $(2.16 \pm 0.01 \%$ of BW $)$ of a high-protein milk replacer (Diaz et al., 2001; Hammon et al., 2002). During the weaning period, total DMI decreased and corresponded to $1.87 \pm 0.03 \%$ of the BW, whereas the estimated ME supply on a metabolic BW basis was reduced by $30 \%$ relative to what calves were consuming before weaning $(291.54 \pm 1.82 \mathrm{Mcal} /$ $\mathrm{kg}^{75}$ ). Consistent with the general reduction in nutrient supply, ADG was decreased during weaning. Despite the benefits for the calf's performance before weaning and potential future productivity (Khan et al., 2011; Soberon et al., 2012), high milk-allowance programs are questioned because of the delayed consumption of appreciable amounts of solid feed and the potential slower gains during and after weaning, compared with restricted milk feeding (Bach et al., 2013; Hill et al., 2016b). However, although lower than before weaning, the ADG observed during weaning was at least equal to the gains reported for calves under restricted feeding, even during the postweaning phase (Kertz et al., 1979; Quigley et al., 2006; Khan et al., 2007). At the same time, the ADG was greater than those observed in other experiments offering high volumes of milk, which have reported a more exacerbated growth slump during 


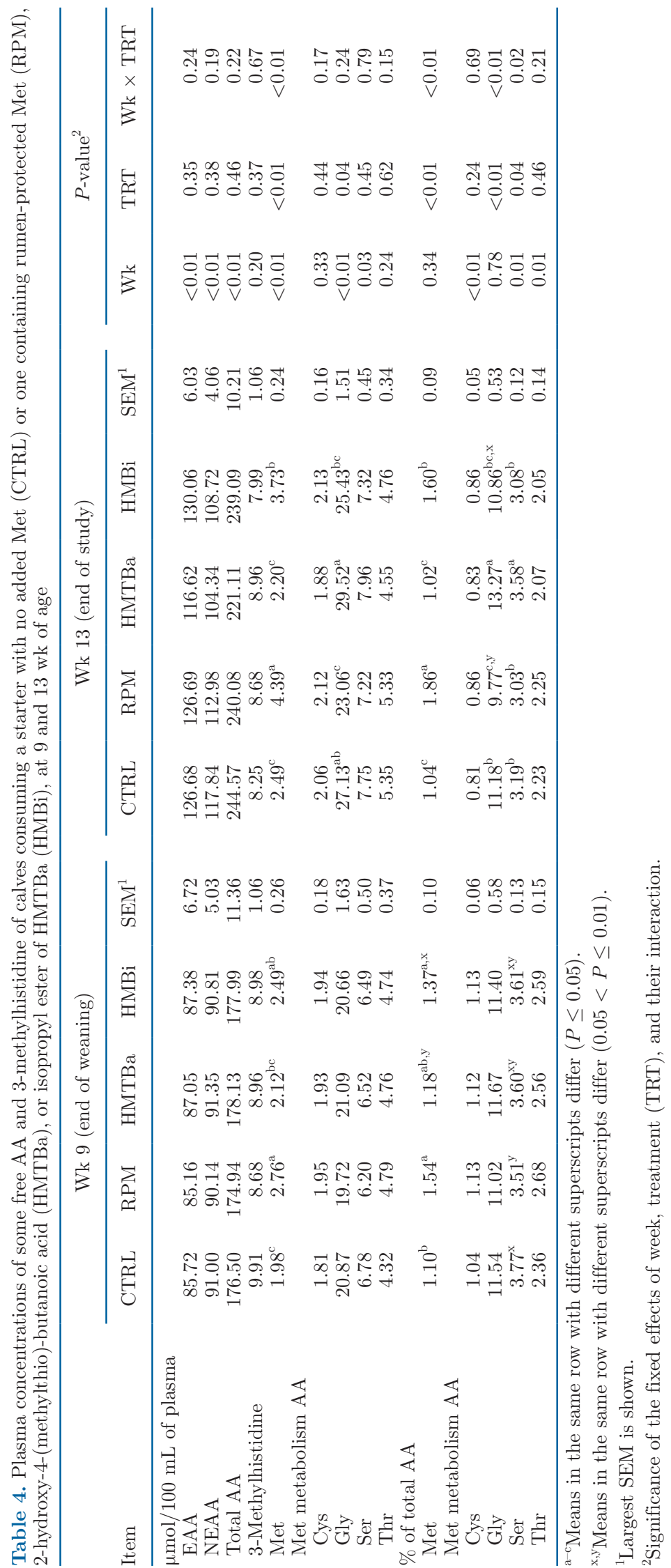


weaning (Terré et al., 2007) and for at least 1 wk to 10 d after weaning (Terré et al., 2006; Stamey et al., 2012). Thus, the present study brings more evidence that with the provision of proper management and starter formulation, postweaning growth reduction can be minimized for calves under an enhanced level of nutrient intake (Molano et al., 2017; Rosenberger et al., 2017; Benetton et al., 2019).

However, the calves were not achieving adequate starter DMI to effectively initiate weaning at $49 \mathrm{~d}$ of age. Greenwood et al. (1997) determined that calves could be weaned when starter DMI corresponds to $1 \%$ of their BW. More recently, Quigley et al. (2019) estimated that calves would have appropriate ruminal development and be prepared for weaning after consuming a cumulative amount of $15 \mathrm{~kg}$ of NFC from starter. In this study, at wk 7 , starter intake was only $0.23 \%$ of calves' BW, and the cumulative NFC intake from starter was $1.6 \mathrm{~kg}$. However, the rapid increase in starter intake immediately after weaning indicated that the rumen was functioning, and the starter formulation allowed for a rapid increase in DMI and reasonable growth through the transition. However, this suggests that, under the feeding management provided in this study, calves could potentially benefit from a further delay of weaning, which is similar to data demonstrating that, with elevated levels of nutrient intake, solid feed and growth could be improved by postponing weaning up to 12 wk of age (de Passillé et al., 2011; Meale et al., 2015). This practice merits consideration, and more information on its biologic and economic implications is warranted.

After weaning, calves grew faster and more efficiently than reported in previous studies evaluating Met (Abe et al., 2000) or Met analog (Williams and Smith, 1974; Hill et al., 2016a) supplementation in weaned calves, where ADG never exceeded $1 \mathrm{~kg} / \mathrm{d}$ and feed efficiencies were less than 0.35 ( $\mathrm{kg}$ ADG $/ \mathrm{kg}$ of DMI). These differences could be due to the differences in the basal diet fed, which, in previous studies, were composed of both concentrates and forage. In addition, calves were feed-restricted in the study by Abe et al. (2000). Recent experiments that offered calves starter and hay ad libitum have observed similar performance and feed efficiency, following weaning, to those observed in the present study (Rosenberger et al., 2017; Benetton et al., 2019), indicating that the digestibility and nutrient balance of the basal diet used in the previous studies evaluating Met supplementation were suboptimal. In previous studies, either the $\mathrm{CP}$ of the starter was low $(13.5$ to $15 \%)$ or the forage was very mature (NDF $>64 \%$ ), or a combination of these factors. The preweaning feeding and management of calves could also explain the lower performance observed after weaning in the other studies. For example, Hill et al. (2016a) started with weaned male Holstein calves weighing only $72 \mathrm{~kg}$ at $59 \mathrm{~d}$ of life, which, at $119 \mathrm{~d}$ of age, weighed approximately $130 \mathrm{~kg}$ across treatments. In the present study, calves reached those BW by approximately 35 and $91 \mathrm{~d}$ of age, respectively. This further reinforces the idea that the growth advantages obtained through an enhanced plan of nutrition prior to weaning could be maintained through continued provision of adequate management and nutrition in the subsequent stages, and this approach better sustains the expression of the calf's biological potential and is necessary to delineate requirements for nutrients such as $\mathrm{AA}$.

The increased plasma Met concentration supported the expectations and predictions for greater metabolizable Met supply from the RPM and HMBi starters to calves. This also demonstrates that HMTBa was not as effective as the other sources in supplying Met to calves, most likely because this analog was metabolized ruminally, as reported in mature ruminants (Chen et al., 2011; Feng et al., 2018). Although rumen function is not fully developed in calves before and during weaning, it is active when they consume solid feed (Quigley et al., 1985; Dennis et al., 2018; Gelsinger et al., 2019). The increased concentration of plasma Met obtained with the inclusion of HMBi further supports the idea that in calves, as described in mature ruminants, HMBi was not as ruminally available as HMTBa, and that it was rapidly absorbed through the ruminal wall before being metabolized in the rumen and transformed into HMTBa (Graulet et al., 2005). These results also confirm the calf's capacity to synthetize Met from its analog as described in vitro (Belasco, 1972). Changes in plasma Met observed in the present study agree with those observed in calves fed Met hydroxy analogs (Muller and Rodriguez, 1975; Schwab, 1980) and in mature ruminants supplemented with the different Met sources (Graulet et al., 2005; St-Pierre and Sylvester, 2005; Ordway et al., 2009).

The greater total DMI and nutrient supply observed at wk 8 for calves fed the RPM starter, compared with those in the CTRL group, was driven by an increased intake of milk replacer, as no difference in starter intake was detected at this point. This observation appears to be somewhat novel in animals of this age and weight, and is difficult to associate with the Met supplementation. Several studies have observed augmented DMI when Met has been supplemented, at levels expected to meet the calves' requirements, in calves (Abe et al., 2000; Hill et al., 2008) and dairy cattle during early lactation (Ordway et al., 2009; Osorio et al., 2013; Batistel et al., 2017). However, the effects of the Met analogs, and not the RPM, on starter intake after weaning indicate that mechanisms other than increased Met 
supply were involved. Although both Met analog products were included at a rate that provided equivalent amounts of HMTBa in the starters, they altered DMI differently, and this occurred only after calves were weaned. Therefore, calves needed to achieve a certain level of starter intake and ruminal activity for the Met analogs to be effective, suggesting that energy intake was likely limiting, given the level of Met consumed. The intake-promoting effect of HMBi suggests that a mechanism linked to its partial ruminal metabolism, and not to the additional Met supplied per se, might be involved in this response, given that supplementation of both RPM and HMBi increased Met supply after weaning, but RPM did not alter intake during this period, compared with the control diet. Chen et al. (2011) also observed that HMBi tended to increase DMI compared with RPM in lactating dairy cows. Thus, although both Met analog products provided equivalent quantities of HMTBa, given the level of inclusion and starter intake after weaning, the HMTBa, mostly available in the rumen, negatively influenced feed consumption, whereas $\mathrm{HMBi}$, metabolized ruminally only in part, had the opposite effect. Nonetheless, it is still uncertain whether the ruminal effect on its own, or in conjunction with the additional Met supply, is responsible for the stimulatory effect of HMBi on intake. Given that changes in starter intake with the analogs were accompanied by differences in BW during the last weeks of experimentation, it seems reasonable that no differences between these groups and the CTRL group could be detected when DMI was adjusted to a BW basis. However, we failed to detect differences in BW gain between the HMBi and CTRL groups, even though calves receiving the HMBi diet were almost $4 \mathrm{~kg}$ heavier than the unsupplemented calves by 13 wk. Further research is needed to confirm the benefits of HMBi supplementation in weaned calves and to explore the potential mechanisms involved.

Overall, the data also demonstrate that the Met bioequivalences, and the metabolizability of the different Met sources by the developing ruminant, line up with those determined in adult cattle (Graulet et al., 2005; Noftsger et al., 2005). To our knowledge, the present study is the first to evaluate HMBi supplementation in calf diets and to confirm its effectiveness as a Met source in this type of animal.

Similar to our findings with the HMTBa starter, Muller and Rodriguez (1975) observed a depression in feed consumption, accompanied by reduced growth, in weaned calves fed starters that included 0.25 and $0.50 \%$ Met hydroxy analog. Those authors hypothesized that these effects could have been due to an excess or imbalance of AA, based on the observed changes in plasma AA, which revealed lower levels of all EAA and higher concentrations of the NEAA related to Met metabo- lism, such as cysteine and glycine. A similar pattern of circulating AA was observed in calves fed HMTBa at the end of the present study. Although no change occurred in plasma Met or Cys, the increase in glycine and serine supports the idea that HMTBa, or its derivatives, affected intake due to an aberrant metabolism of their methyl groups (Benevenga, 1974). This observation is indicated because, although plasma Met increased after weaning in calves consuming starters with RPM and HMBi, levels of the other AA involved in its metabolism were reduced or unchanged. The Met hydroxy analog has been shown to affect calves' performance when consumed between 7.50 to $13.55 \mathrm{~g} / 100$ $\mathrm{kg}$ of BW (Muller and Rodriguez, 1975). In the current study, HMTBa was included at $0.33 \%$ of DM, which resulted in analog intakes of $0.4,3.0$, and $8.8 \mathrm{~g}$ per $100 \mathrm{~kg}$ of BW before, during, and after weaning, respectively. Thus, at almost $9 \mathrm{~g}$ per $100 \mathrm{~kg}$ of intake, this might be the reason why the HMTBa starter affected intake only in the last period of the trial and not before. Differences in feed efficiency were not observed between calves consuming the HMTBa starter and those fed the CTRL diet, implying that the growth reduction observed after weaning with this analog was mainly due to the lower nutrient intake. In any case, we failed to anticipate this undesired effect when setting the inclusion level of the HMTBa product and compromised our intention to use the HMTBa-fed group as a reference for the potential ruminal effect that both Met analogs might have. Future research with these analogs should feed them in amounts that provide equivalent quantities of ruminally active HMTBa, instead of total HMTBa as done here.

Several studies have estimated calf Met requirements. Using plasma AA and urea concentrations as criteria, Met requirements were estimated by Williams and Smith for ruminant calves weighing between 110 and $160 \mathrm{~kg}$, growing at $0.4 \mathrm{~kg} / \mathrm{d}(1974)$, and for liquidfed calves weighing $54 \mathrm{~kg}$, gaining $0.25 \mathrm{~kg} / \mathrm{d}$ (1975). Also, Abe et al. (1998) estimated this requirement for weaned calves close to $75 \mathrm{~kg}$, growing at $0.56 \mathrm{~kg} / \mathrm{d}$, by analyzing nitrogen retention and plasma AA concentrations. It is important to note that in these studies, animals were not fed ad libitum, and therefore no effects on DMI or growth were reported. More recent work with young calves weighing approximately $48 \mathrm{~kg}$, fed a maximum of $0.65 \mathrm{~kg} / \mathrm{d}$ of milk replacer solids, and growing at $0.4 \mathrm{~kg} / \mathrm{d}$, determined optimal levels of Met in the milk replacer that allowed greater starter intake, growth, and feed efficiency (Hill et al., 2008). Due to the different BW of calves and various diets employed in these studies, comparing their requirement estimations is difficult. However, when we scale them to MBW, most fall between 0.2 and $0.4 \mathrm{~g}$ of Met flowing 
to the intestine per kilogram of MBW. Then, based on the predicted metabolizable Met supply relative to MBW in the present study, the Met requirement of calves might have been achieved through intake of the CTRL starter. Nonetheless, the additional amounts of Met provided with RPM and HMBi were still within the safe levels established for dairy calves of similar weight to those studied here (Abe et al., 2000).

One consideration for this study was that Cys requirements were being met through Met supplementation, and the target ADG was greater than $1 \mathrm{~kg} / \mathrm{d}$; thus, demands for sulfur AA were high. For example, Patureau-Mirand et al. (1973) studied Met and Cys supplementation in liquid-fed calves that performed similarly to those in our study (approximately $80 \mathrm{~kg}$ BW and $1.1 \mathrm{~kg} / \mathrm{d}$ ADG) and, analyzing plasma Met levels, estimated requirements that corresponded to $0.53 \mathrm{~g}$ of Met $/ \mathrm{kg}^{0.75}$, whereas the intake of both Met and Cys was $0.67 \mathrm{~g} / \mathrm{kg}^{0.75}$. Currently, nutritional models for dairy cattle such as the NRC (2001) or CNCPS (Van Amburgh et al., 2015a) do not consider NEAA; however, for others species, such as swine (NRC, 2012), models have included Cys because Cys requirements could be met by the transsulfuration of Met, and therefore the requirement of Met would depend on the Cys balance. Considering that Cys content is 92 and $83 \%$ that of Met in the base starter (Table 2) and rumen bacteria (Sok et al., 2017), respectively, it was estimated that the metabolizable sulfur AA supply during the postweaning period was $0.51,0.65$, and $0.74 \mathrm{~g} /$ $\mathrm{kg}^{0.75}$ for calves fed the CTRL, HMBi, and RPM diets, respectively.

Considering that AA requirements should correspond to the supply at which efficiency of nutrient use and growth are optimized, our results during the postweaning period do not support the Met requirements established by Patureau-Mirand et al. (1973) for preweaned calves, because no differences in growth, feed efficiency, or PUN were detected with the additional supply of Met alone. This inconsistency might have arisen by the lower caloric intake of calves in our study postweaning (253 kcal of ME $/ \mathrm{kg}^{0.75}$ ) compared with that estimated for preruminant calves in the study of Patureau-Minard et al., consuming milk replacer only (326 kcal of ME/ $\mathrm{kg}^{0.75}$, which might have prevented the potential benefit of the additional Met on calves' performance and nutrient utilization. Thus, energy and not Met could have been first limiting growth in this study, given the basal Met content of the CTRL diet. This idea is reinforced by the observation that, although the inclusion of HMBi did not supply as much Met as the RPM, demonstrated by lower predicted supply and plasma levels, the increased ME supply due to increased DMI with this analog resulted in heavier calves at the end of the study. Recognizing that energy intake could limit protein deposition, nutritional models have been developed to express AA requirements as constant dietary AA to energy ratios for swine (NRC, 2012) and lactating dairy cows (Higgs and Van Amburgh, 2016). These ratios have not yet been established for the growing ruminant.

When Met and other EAA have been supplemented at levels that meet the estimated requirements, improvements in growth or $\mathrm{N}$ retention have been accompanied by reduction in PUN concentrations in pre-ruminant animals (Williams and Smith, 1975; Hill et al., 2008), suggesting better utilization of dietary nitrogen. However, an effect in PUN has not always been observed in ruminant calves (Williams and Smith, 1974; Schwab et al., 1982). This supports the observation of similar PUN levels between calves receiving additional Met through RPM or HMBi and the CTRL group. As calves consumed more solid feed, the overall increase in PUN most likely originated from the ammonia produced by protein breakdown in the rumen. A similar increase of PUN concentrations has been previously described in calves during their progression to the ruminant state (Khan et al., 2007; Molano et al., 2017). The association between the quantity of starter consumed and PUN was weak $(\mathrm{r}=0.38, P<0.001)$, indicating that accumulation of PUN with age is also related to other processes occurring in ruminants, such as nitrogen recycling (Berends et al., 2014).

As described by Deelen et al. (2016) blood BHB is highly associated with rumen total VFA and butyrate production. In agreement with these findings, circulating BHB and starter intake in this study were well correlated $(\mathrm{r}=0.79 ; P<0.001)$, supporting the idea that starter was being fermented and butyrate was being ruminally produced. This association and the observation that no differences in circulating BHB were detected, whereas starter intake was affected by the Met analogs after weaning, might indicate that the ruminal fermentation pattern was altered differently by the Met analogs during this period. In developed ruminants, Martin et al. (2013) found that both analogs increased total VFA ruminal concentration, whereas HMBi reduced the butyrate molar proportion compared with HMTBa. However, results from other in vivo and in vitro studies have found contrasting effects of these analogs on ruminal fermentation (Fowler et al., 2015; Feng et al., 2018). In the present study, and in previous work where calves were fed a similar starter to our CTRL (Molano et al., 2017), calves had higher circulating BHB at similar levels of starter intake, compared with those reported by Eckert et al. (2015), Deelen et al. (2016), and Suarez-Mena et al. (2017). The combined feeding of starter and forage, and the scarce feed chemistry re- 
ported in later studies, limits comparison with the present study. Nonetheless, the greater levels of circulating BHB observed here could be partially attributable to the higher sugar and lower starch content of the starter, along with the higher digestible NDF and soluble fiber intakes, which favor greater ruminal butyrate production (Morvay et al., 2011). Among the VFA produced ruminally, butyrate is the main promoter of rumen mucosa development (Sander et al., 1959). This suggests that the carbohydrate characteristics of the starters fed in the present study could have fostered ruminal development to a greater extent than those of diets provided in the other experiments. This hypothesis deserves consideration. More research on the carbohydrate profiles of calf starters and their effects on rumen development and overall performance is warranted.

\section{CONCLUSIONS}

Inclusion of RPM (as Smartamine M) or HMBi (as MetaSmart) in calf starters was effective to provide metabolizable Met to the weaned calf, as indicated by the augmented levels of circulating free Met. However, under the conditions of this study, calves appeared not to be limited by Met, because no improvement in growth or feed efficiency could be related solely to the additional Met supplied. After weaning, HMBi promoted nutrient intake, resulting in heavier calves at the end of the experiment. The ruminal metabolism of HMBi, on its own or in conjunction with additional Met, seems to be the mechanism involved in this response, and this needs to be further investigated. At the levels included in the starter, HMTBa (as RumenSmart) did not provide increased metabolizable Met for weaned calves but, instead, seemed to create an imbalance, given the changes observed in plasma AA combined with the negative influence on intake and growth. More work is needed to refine Met requirements, and those of EAA in general, for calves growing at rates closer to their biological potential.

\section{ACKNOWLEDGMENTS}

The authors are grateful to Adisseo (Commetry, France, and Alpharetta, GA) for support and partial funding of the study. In addition, we thank Milk Specialties Global (Eden Prairie, MN) for their financial contribution to this work. We thank Zen Raku Ren (Tokyo, Japan) as well, for their financial contribution for this research. We also acknowledge Poulin Grain (Newport, VT) for their valuable support manufacturing and for providing the starters for this trial, as well as M. J. Dineen, J. Q. Fouts, P. A. LaPierre, and A. F. Ortega (Cornell University, Ithaca, NY) for assistance with animal management and sample collection. This trial would not have been possible without the collaboration of the Cornell University Ruminant Center staff. The authors declare no conflicts of interest.

\section{REFERENCES}

Abe, M., T. Iriki, M. Funaba, and S. Onda. 1998. Limiting amino acids for a corn and soybean meal diet in weaned calves less than three months of age. J. Anim. Sci. 76:628-636. https://doi.org/10.2527/ 1998.762628x.

Abe, M., H. Okada, D. Matsumura, H. Sato, M. Funaba, and T. Iriki. 2000. Methionine imbalance and toxicity in calves. J. Anim. Sci. 78:2722-2730. https://doi.org/10.2527/2000.78102722x.

AOAC. 2000. Official Methods of Analysis. 17th ed. Assoc. Off. Anal. Chem., Gaithersburg, MD.

AOAC. 2006. Official Methods of Analysis. 18th ed. Assoc. Off. Anal. Chem., Gaithersburg, MD.

Bach, A., M. Terré, and A. Pinto. 2013. Performance and health responses of dairy calves offered different milk replacer allowances. J. Dairy Sci. 96:7790-7797. https://doi.org/10.3168/jds.2013-6909.

Bartlett, K. S., F. K. McKeith, M. J. VandeHaar, G. E. Dahl, and J. K. Drackley. 2006. Growth and body composition of dairy calves fed milk replacers containing different amounts of protein at two feeding rates. J. Anim. Sci. 84:1454-1467. https://doi.org/10 $.2527 / 2006.8461454 x$.

Bates, D., M. Mächler, B. Bolker, and S. Walker. 2015. Fitting linear mixed-effects models using lme4. J. Stat. Softw. 67:1-48. https:// doi.org/10.18637/jss.v067.i01.

Batistel, F., J. Arroyo, A. Bellingeri, L. Wang, B. Saremi, C. Parys, E. Trevisi, F. Cardoso, and J. J. Loor. 2017. Ethyl-cellulose rumenprotected methionine enhances performance during the periparturient period and early lactation in Holstein dairy cows. J. Dairy Sci. 100:7455-7467. https://doi.org/10.3168/jds.2017-12689.

Belasco, I. J. 1972. Stability of methionine hydroxy analog in rumen fluid and its conversion in vitro to methionine by calf liver and kidney. J. Dairy Sci. 55:353-357. https://doi.org/10.3168/jds.S0022 -0302(72)85496-1.

Benetton, J. B., H. W. Neave, J. H. C. Costa, M. A. G. von Keyserlingk, and D. M. Weary. 2019. Automatic weaning based on individual solid feed intake: Effects on behavior and performance of dairy calves. J. Dairy Sci. 102:5475-5491. https://doi.org/10 .3168/jds.2018-15830.

Benevenga, N. J. 1974. Toxicities of methionine and other amino acids. J. Agric. Food Chem. 22:2-9. https://doi.org/10.1021/jf60191a036.

Berends, H., J. J. van den Borne, B. A. Røjen, J. van Baal, and W. J. Gerrits. 2014. Urea recycling contributes to nitrogen retention in calves fed milk replacer and low-protein solid feed. J. Nutr. 144:1043-1049. https://doi.org/10.3945/jn.114.191353.

Chaney, A. L., and E. P. Marbach. 1962. Modified reagents for determination of urea and ammonia. Clin. Chem. 8:130-132. https:// doi.org/10.1093/clinchem/8.2.130.

Chen, Z. H., G. A. Broderick, N. D. Luchini, B. K. Sloan, and E. Devillard. 2011. Effect of feeding different sources of rumen-protected methionine on milk production and N-utilization in lactating dairy cows. J. Dairy Sci. 94:1978-1988. https://doi.org/10.3168/jds.2010 -3578 .

de Passillé, A. M., T. F. Borderas, and J. Rushen. 2011. Weaning age of calves fed a high milk allowance by automated feeders: Effects on feed, water, and energy intake, behavioral signs of hunger, and weight gains. J. Dairy Sci. 94:1401-1408. https://doi.org/10.3168/ jds.2010-3441.

Deelen, S. M., K. E. Leslie, M. A. Steele, E. Eckert, H. E. Brown, and T. J. DeVries. 2016. Validation of a calf-side $\beta$-hydroxybutyrate test and its utility for estimation of starter intake in dairy calves around weaning. J. Dairy Sci. 99:7624-7633. https://doi.org/10 .3168/jds.2016-11097.

Dennis, T. S., F. X. Suarez-Mena, T. M. Hill, J. D. Quigley, R. L. Schlotterbeck, and L. Hulbert. 2018. Effect of milk replacer feed- 
ing rate, age at weaning, and method of reducing milk replacer to weaning on digestion, performance, rumination, and activity in dairy calves to 4 months of age. J. Dairy Sci. 101:268-278. https:/ /doi.org/10.3168/jds.2017-13692.

Diaz, M. C., M. E. Van Amburgh, J. M. Smith, J. M. Kelsey, and E. L. Hutten. 2001. Composition of growth of Holstein calves fed milk replacer from birth to 105-kilogram body weight. J. Dairy Sci. 84:830-842. https://doi.org/10.3168/jds.S0022-0302(01)74541-9.

DuBois, M., K. A. Gilles, J. K. Hamilton, P. Rebers, and F. Smith. 1956. Colorimetric method for determination of sugars and related substances. Anal. Chem. 28:350-356. https://doi.org/10.1021/ ac60111a017.

Eckert, E., H. E. Brown, K. E. Leslie, T. J. DeVries, and M. A. Steele. 2015. Weaning age affects growth, feed intake, gastrointestinal development, and behavior in Holstein calves fed an elevated plane of nutrition during the preweaning stage. J. Dairy Sci. 98:6315-6326. https://doi.org/10.3168/jds.2014-9062.

Feng, X., R. White, H. Tucker, and M. Hanigan. 2018. Meta-analysis of 2-hydroxy-4-methylthio-butanoic acid supplementation on ruminal fermentation, milk production, and nutrient digestibility. J. Dairy Sci. 101:7182-7189. https://doi.org/10.3168/jds.2017-13847.

Fessenden, S. W., T. J. Hackmann, D. A. Ross, A. Foskolos, and M. E. Van Amburgh. 2017. Ruminal bacteria and protozoa composition, digestibility, and amino acid profile determined by multiple hydrolysis times. J. Dairy Sci. 100:7211-7226. https://doi.org/10 $.3168 /$ jds.2016-12531.

Fowler, C. M., J. E. Plank, E. Devillard, B. J. Bequette, and J. L. Firkins. 2015. Assessing the ruminal action of the isopropyl ester of 2-hydroxy-4-(methylthio) butanoic acid in continuous and batch cultures of mixed ruminal microbes. J. Dairy Sci. 98:1167-1177. https://doi.org/10.3168/jds.2014-8692.

Gelsinger, S. L., W. K. Coblentz, G. I. Zanton, R. K. Ogden, and M. S. Akins. 2019. Ruminal in situ disappearance and whole-tract digestion of starter feeds in calves before, during, and after weaning. J. Dairy Sci. 102:2196-2206. https://doi.org/10.3168/jds.2018-15551.

Graulet, B., C. Richard, and J. Robert. 2005. Methionine availability in plasma of dairy cows supplemented with methionine hydroxy analog isopropyl ester. J. Dairy Sci. 88:3640-3649. https://doi .org/10.3168/jds.S0022-0302(05)73049-6.

Greenwood, R. H., J. L. Morrill, and E. C. Titgemeyer. 1997. Using dry feed intake as a percentage of initial body weight as a weaning criterion. J. Dairy Sci. 80:2542-2546. https://doi.org/10.3168/jds S0022-0302(97)76208-8.

Hall, M. B. 2009. Determination of starch, including maltooligosaccharides, in animal feeds: Comparison of methods and a method recommended for AOAC collaborative study. J. AOAC Int. 92:42-49. https://doi.org/10.1093/jaoac/92.1.42.

Hammon, H. M., G. Schiessler, A. Nussbaum, and J. W. Blum. 2002. Feed intake patterns, growth performance, and metabolic and endocrine traits in calves fed unlimited amounts of colostrum and milk by automate, starting in the neonatal period. J. Dairy Sci. 85:3352-3362. https://doi.org/10.3168/jds.S0022-0302(02)74423 $-8$.

Higgs, R., and M. Van Amburgh. 2016. Evolution of the CNCPSDevelopment of V7. Pages 125-144 in Proc. Cornell Nut. Conf., East Syracuse, NY. Cornell University, Ithaca, NY.

Hill, T., J. Aldrich, R. Schlotterbeck, and H. Bateman II.. 2007. Protein concentrations for starters fed to transported neonatal calves. Prof. Anim. Sci. 23:123-134. https://doi.org/10.15232/S1080 -7446(15)30952-9.

Hill, T. M., H. G. Bateman II, J. M. Aldrich, R. L. Schlotterbeck, and K. G. Tanan. 2008. Optimal concentrations of lysine, methionine, and threonine in milk replacers for calves less than five weeks of age. J. Dairy Sci. 91:2433-2442. https://doi.org/10.3168/jds.2007 -0610 .

Hill, T. M., J. D. Quigley, H. G. Bateman II, J. M. Aldrich, and R. L. Schlotterbeck. 2016a. Source of carbohydrate and metabolizable lysine and methionine in the diet of recently weaned dairy calves on digestion and growth. J. Dairy Sci. 99:2788-2796. https://doi .org/10.3168/jds.2015-10571.
Hill, T. M., J. D. Quigley, F. X. Suarez-Mena, H. G. Bateman II, and R. L. Schlotterbeck. 2016b. Effect of milk replacer feeding rate and functional fatty acids on dairy calf performance and digestion of nutrients. J. Dairy Sci. 99:6352-6361. https://doi.org/10.3168/ jds.2015-10812.

Kertz, A., L. Prewitt, and J. Everett Jr.. 1979. An early weaning calf program: Summarization and review. J. Dairy Sci. 62:1835-1843. https://doi.org/10.3168/jds.S0022-0302(79)83508-0.

Khan, M. A., H. J. Lee, W. S. Lee, H. S. Kim, S. B. Kim, K. S. Ki, J. K. Ha, H. G. Lee, and Y. J. Choi. 2007. Pre-and postweaning performance of Holstein female calves fed milk through step-down and conventional methods. J. Dairy Sci. 90:876-885. https://doi .org/10.3168/jds.S0022-0302(07)71571-0.

Khan, M. A., D. M. Weary, and M. A. von Keyserlingk. 2011. Invited review: effects of milk ration on solid feed intake, weaning, and performance in dairy heifers. J. Dairy Sci. 94:1071-1081. https:// doi.org/10.3168/jds.2010-3733.

Leibholz, J. 1975. The development of ruminant digestion in the calf. I. The digestion of barley and soya bean meal. Aust. J. Agric. Res. 26:1081-1091. https://doi.org/10.1071/AR9751081.

Lenth, R., H. Singmann, J. Love, P. Buerkner, and M. Herve. 2019. emmeans: Estimated Marginal Means, aka Least-Squares Means. Accessed Nov. 25, 2019. https://cran.r-project.org/web/packages/ emmeans/index.html.

Luchini, N. D., S. F. Lane, and D. K. Combs. 1991. Evaluation of starter diet crude protein level and feeding regimen for calves weaned at 26 days of age. J. Dairy Sci. 74:3949-3955. https://doi .org/10.3168/jds.S0022-0302(91)78589-5.

Martin, C., C. Mirande, D. Morgavi, E. Forano, E. Devillard, and P. Mosoni. 2013. Methionine analogues HMB and HMBi increase the abundance of cellulolytic bacterial representatives in the rumen of cattle with no direct effects on fibre degradation. Anim. Feed Sci. Technol. 182:16-24. https://doi.org/10.1016/j.anifeedsci.2013 .03.008.

Meale, S., L. Leal, J. Martín-Tereso, and M. Steele. 2015. Delayed weaning of Holstein bull calves fed an elevated plane of nutrition impacts feed intake, growth and potential markers of gastrointestinal development. Anim. Feed Sci. Technol. 209:268-273. https:// doi.org/10.1016/j.anifeedsci.2015.08.008.

Mertens, D. R. 2002. Gravimetric determination of amylase-treated neutral detergent fiber in feeds with refluxing in beakers or crucibles: Collaborative study. J. AOAC Int. 85:1217-1240.

Molano, R., C. Girard, and M. Van Amburgh. 2017. Effect of dietary supplementation of two forms of a B-vitamin and choline blend on the performance of Holstein calves during the transition and early postweaning period. Pages 52-65 in Proc. Cornell Nutr. Conf., Syracuse, NY. Cornell University, Ithaca, NY.

Morvay, Y., A. Bannink, J. France, E. Kebreab, and J. Dijkstra. 2011. Evaluation of models to predict the stoichiometry of volatile fatty acid profiles in rumen fluid of lactating Holstein cows. J. Dairy Sci. 94:3063-3080. https://doi.org/10.3168/jds.2010-3995.

Muller, L. D., and D. Rodriguez. 1975. Methionine hydroxy analog supplementation of low protein calf rations. J. Dairy Sci. 58:190195. https://doi.org/10.3168/jds.S0022-0302(75)84543-7.

National Research Council. 2001. Nutrient Requirements of Dairy Cattle. 7th rev. ed. Natl. Acad. Press, Washington, DC.

National Research Council. 2012. Nutrient Requirements of Swine. 11th ed. Natl. Acad. Press, Washington, DC.

Noftsger, S., N. St-Pierre, and J. Sylvester. 2005. Determination of rumen degradability and ruminal effects of three sources of methionine in lactating cows. J. Dairy Sci. 88:223-237. https://doi .org/10.3168/jds.S0022-0302(05)72680-1.

Ordway, R. S., S. E. Boucher, N. L. Whitehouse, C. G. Schwab, and B. K. Sloan. 2009. Effects of providing two forms of supplemental methionine to periparturient Holstein dairy cows on feed intake and lactational performance. J. Dairy Sci. 92:5154-5166. https:// doi.org/10.3168/jds.2009-2259.

Osorio, J. S., P. Ji, J. K. Drackley, D. Luchini, and J. J. Loor. 2013. Supplemental Smartamine M or MetaSmart during the transition period benefits postpartal cow performance and blood neutrophil 
function. J. Dairy Sci. 96:6248-6263. https://doi.org/10.3168/jds $2012-5790$

Patureau-Mirand, P., J. Prugnaud, R. Pion, F. Barré, M.-C. Valluy, A. Selle, and M. Sallas. 1973. Influence de la supplementation en acides amines soufres d'un aliment d'allaitement sur l'amino-acidemie estimation du besoin en methionine du veau pre-ruminant. Pages 225-246 in Proc. Annales de Biologie Animale Biochimie Biophysique. EDP Sciences, Les Ulis, France.

Quigley, J. D. III, C. G. Schwab, and W. E. Hylton. 1985. Development of rumen function in calves: Nature of protein reaching the abomasum. J. Dairy Sci. 68:694-702. https://doi.org/10.3168/jds .S0022-0302(85)80875-4.

Quigley, J. D., T. A. Wolfe, and T. H. Elsasser. 2006. Effects of additional milk replacer feeding on calf health, growth, and selected blood metabolites in calves. J. Dairy Sci. 89:207-216. https://doi .org/10.3168/jds.S0022-0302(06)72085-9.

Quigley, J. D. III., and J. J. Drewry. 1998. Nutrient and immunity transfer from cow to calf pre- and postcalving. J. Dairy Sci. 81:2779-2790. https://doi.org/10.3168/jds.S0022-0302(98)75836 -9 .

Quigley, J. D., W. Hu, J. R. Knapp, T. S. Dennis, F. X. Suarez-Mena, and T. M. Hill. 2019. Estimates of calf starter energy affected by consumption of nutrients. 2. Effect of changing digestion on energy content in calf starters. J. Dairy Sci. 102:2242-2253. https://doi .org/10.3168/jds.2018-15354.

R Core Team. 2019. R: A Language and Environment for Statistical Computing. Version R 3.6.0. R foundation for statistical computing, Vienna, Austria.

Rosenberger, K., J. H. C. Costa, H. W. Neave, M. A. G. von Keyserlingk, and D. M. Weary. 2017. The effect of milk allowance on behavior and weight gains in dairy calves. J. Dairy Sci. 100:504-512. https://doi.org/10.3168/jds.2016-11195.

Rutherfurd, S. M. 2009. Accurate determination of the amino acid content of selected feedstuffs. Int. J. Food Sci. Nutr. 60(Suppl. 7):53-62. https://doi.org/10.1080/09637480802269957.

Sander, E., R. Warner, H. Harrison, and J. Loosli. 1959. The stimulatory effect of sodium butyrate and sodium propionate on the development of rumen mucosa in the young calf. J. Dairy Sci. 42:1600-1605. https://doi.org/10.3168/jds.S0022-0302(59)90772 $-6$.

Schwab, C. G. 1980. Supplementation of low protein calf starter rations with N-hydroxymethyl-DL-methionine-Ca and di-hydroxymethyl-L-lysine-Ca. Nut. Rep. Int. 22:811-821.

Schwab, C. G., S. J. Muise, W. E. Hylton, and J. J. Moore III.. 1982. Response to abomasal infusion of methionine of weaned dairy calves fed a complete pelleted starter ration based on by-product feeds. J. Dairy Sci. 65:1950-1961. https://doi.org/10.3168/jds .S0022-0302(82)82444-2.

Soberon, F., E. Raffrenato, R. W. Everett, and M. E. Van Amburgh. 2012. Preweaning milk replacer intake and effects on long-term productivity of dairy calves. J. Dairy Sci. 95:783-793. https://doi .org/10.3168/jds.2011-4391.

Sok, M., D. Ouellet, J. Firkins, D. Pellerin, and H. Lapierre. 2017. Amino acid composition of rumen bacteria and protozoa in cattle. J. Dairy Sci. 100:5241-5249. https://doi.org/10.3168/jds.2016 $-12447$.

St-Pierre, N. R., and J. T. Sylvester. 2005. Effects of 2-hydroxy4-(methylthio) butanoic acid (HMB) and its isopropyl ester on milk production and composition by Holstein cows. J. Dairy Sci. 88:2487-2497. https://doi.org/10.3168/jds.S0022-0302(05)72926 $-\mathrm{X}$.

Stamey, J. A., N. A. Janovick, A. F. Kertz, and J. K. Drackley. 2012. Influence of starter protein content on growth of dairy calves in an enhanced early nutrition program. J. Dairy Sci. 95:3327-3336. https://doi.org/10.3168/jds.2011-5107.

Suárez, B. J., C. G. Van Reenen, G. Beldman, J. van Delen, J. Dijkstra, and W. J. J. Gerrits. 2006. Effects of supplementing concentrates differing in carbohydrate composition in veal calf diets: I. Animal performance and rumen fermentation characteristics.
J. Dairy Sci. 89:4365-4375. https://doi.org/10.3168/jds.S0022 -0302(06)72483-3.

Suarez-Mena, F. X., W. Hu, T. S. Dennis, T. M. Hill, and R. L. Schlotterbeck. 2017. $\beta$-Hydroxybutyrate (BHB) and glucose concentrations in the blood of dairy calves as influenced by age, vaccination stress, weaning, and starter intake including evaluation of BHB and glucose markers of starter intake. J. Dairy Sci. 100:2614-2624. https://doi.org/10.3168/jds.2016-12181.

Terré, M., A. Bach, and M. Devant. 2006. Performance and behaviour of calves reared in groups or individually following an enhancedgrowth feeding programme. J. Dairy Res. 73:480-486. https://doi .org/10.1017/S0022029906002019.

Terré, M., M. Devant, and A. Bach. 2007. Effect of level of milk replacer fed to Holstein calves on performance during the preweaning period and starter digestibility at weaning. Livest. Sci. 110:82-88. https://doi.org/10.1016/j.livsci.2006.10.001.

Tikofsky, J. N., M. E. Van Amburgh, and D. A. Ross. 2001. Effect of varying carbohydrate and fat content of milk replacer on body composition of Holstein bull calves. J. Anim. Sci. 79:2260-2267. https://doi.org/10.2527/2001.7992260x.

Van Amburgh, M. E., E. A. Collao-Saenz, R. J. Higgs, D. A. Ross, E. B. Recktenwald, E. Raffrenato, L. E. Chase, T. R. Overton, J. K. Mills, and A. Foskolos. 2015a. The Cornell Net Carbohydrate and Protein System: Updates to the model and evaluation of version 6.5. J. Dairy Sci. 98:6361-6380. https://doi.org/10.3168/jds.2015 -9378 .

Van Amburgh, M. E., A. Foskolos, and R. J. Higgs. 2015b. Balancing diets with the CNCPS v6.5-What's changed and implications for use. Pages 115-122 in Proc. Cornell Nutrition Conference, Syracuse, NY. Cornell University, Ithaca, NY.

Van Amburgh, M. E., F. Soberon, M. J. Meyer, and R. A. Molano. 2019. Symposium review: Integration of postweaning nutrient requirements and supply with composition of growth and mammary development in modern dairy heifers. J. Dairy Sci. 102:3692-3705. https://doi.org/10.3168/jds.2018-15270.

Van Soest, P. J., J. B. Robertson, and B. A. Lewis. 1991. Methods for dietary fiber, neutral detergent fiber, and nonstarch polysaccharides in relation to animal nutrition. J. Dairy Sci. 74:3583-3597. https://doi.org/10.3168/jds.S0022-0302(91)78551-2.

Weary, D. M., J. Jasper, and M. J. Hötzel. 2008. Understanding weaning distress. Appl. Anim. Behav. Sci. 110:24-41. https://doi.org/ 10.1016/j.applanim.2007.03.025.

Williams, A. P., and R. H. Smith. 1974. Concentrations of amino acids and urea in the plasma of the ruminating calf and estimation of the amino acid requirements. Br. J. Nutr. 32:421-433. https://doi .org/10.1079/BJN19740094.

Williams, A. P., and R. H. Smith. 1975. Concentrations of amino acids and urea in the plasma of the preruminant calf and estimation of the amino acid requirements. Br. J. Nutr. 33:149-158. https://doi .org/10.1079/BJN19750020.

Williams, A. P. 1978. The amino acid, collagen and mineral composition of preruminant calves. J. Agric. Sci. 90:617-624. https://doi .org/10.1017/S0021859600056161.

Williamson, D. H., J. Mellanby, and H. A. Krebs. 1962. Enzymic determination of $\mathrm{D}(-)-\beta$-hydroxybutyric acid and acetoacetic acid in blood. Biochem. J. 82:90-96. https://doi.org/10.1042/bj0820090.

Zanton, G. I., G. R. Bowman, M. Vázquez-Añón, and L. M. Rode. 2014. Meta-analysis of lactation performance in dairy cows receiving supplemental dietary methionine sources or postruminal infusion of methionine. J. Dairy Sci. 97:7085-7101. https://doi.org/10 $.3168 /$ jds.2014-8220.

\section{ORCIDS}

Rodrigo A. Molano @ https://orcid.org/0000-0003-4083-1522 Daniel N. Luchini ৫ https://orcid.org/0000-0003-2096-0984 Michael E. Van Amburgh (1 https://orcid.org/0000-0003-3728-6092 